\title{
The Development and Implementation of Learning Material on Exposition Text to Improve Students' Achievement on Bahasa Indonesia
}

\author{
Wenny Silaban ${ }^{1}$, Biner Ambarita ${ }^{1} \&$ Usman Hadi $^{1}$ \\ ${ }^{1}$ Department of Bahasa Indonesia, Graduate Study Program (Program Pascasarjana), Universitas Negeri Medan, \\ Medan, North Sumatera, Indonesia \\ Correspondence: Wenny Silaban, Department of Bahasa Indonesia, Graduate Study Program (Program \\ Pascasarjana), Universitas Negeri Medan (State University Medan), Jl. Willem Iskandar, Psr V, Medan, North \\ Sumatera, Indonesia. E-mail: wensilaban@unimed.ac.id; wennysilaban24@gmail.com
}

Received: June 23, 2018

doi:10.5539/ies.v11n11p53
Accepted: July 28, $2018 \quad$ Online Published: October 29, 2018

URL: https://doi.org/10.5539/ies.v11n11p53

\begin{abstract}
The development and implementation of learning material on exposition text with a process for Senior High School (SHS) students on the teaching of Bahasa Indonesia is reported. The study is aimed to develop a learning material on exposition text with a process to be used as a learning media on the teaching of writing in Bahasa Indonesia. The study is carried out at state senior high school (Sekolah Menengah Atas, SMA) Medan, Indonesia at academic year 2017/2018. The learning material is developed by enriching the topics with exposition text to meet the competence required by national curriculum in Indonesia. The learning material has been used as a media the teaching and learning activities in the experimental class and compared with ordinary book that has been used in control class on the teaching of Bahasa Indonesia. An excellent learning material has been obtained. Implementation of the learning material in the class has change students learning style moving from teacher centred to students centred learning. The developed material was found very effective as a learning media in the teaching and learning process and be able to improve students' achievement in Bahasa Indonesia. Students' achievements in experimental class $(\mathrm{M}=89.63 \pm 5.32)$ was higher than that obtained in control class $(\mathrm{M}=77.25 \pm 5.06)$. The students' writing skills are improved. Students performance in experimental class $(\mathrm{M}=86.04 \pm 6.89)$ was higher than that in control class $(\mathrm{M}=78.60 \pm 5.42)$. The learning facilities provided in the learning material are found to be effective to guide the students to improve their learning ability to write texts on exposition text with a process in Bahasa Indonesia.
\end{abstract}

Keywords: learning material, exposition text, students' achievement, students' performance, writing skills

\section{Introduction}

The development and implementation of learning material on exposition text with a process for the teaching of Bahasa Indonesia is very important, as it is known that a good learning material be able to optimize the learning activities, as a way to achieve a better learning outcomes. The implementation of national curriculum 2013 in Indonesia has bring the students learning style to adopt scientific approaches, where the students tends to be active learner, and the teachers acted as facilitators. One effort to improve the quality of education is through improving the quality learning materials used in the teaching activities (Situmorang, 2013). A learning material plays important roles to help students in the teaching and learning process. It could be used as a complete source of knowledge and the contents in the learning material is easily adjusted with the students' development (Situmorang \& Sinaga, 2015). A well-designed learning material help the students to understand the concept. Various learning material have been used in the teaching and learning activities such as textbook, module, and booklet (Semingson, et al., 2015). It is known that printed learning material is a very genuine a learning resource and it plays an important role in teaching and learning process (Abed \& Al-Absi, 2015). The information in the learning material can be used to strengthen and support the learning topic being taught. It also very helpful as it can be repeated to focus a specific subject (Holliday, 2002).

The learning material on exposition text with a process serves as a student guide on writing in Bahasa Indonesia. Exposition text with a process is the text that can deliver, explain in details, inform something clearly and it 
became a new knowledge to the readers (Kirsch \& Mosenthal, 1992). It has been used in academic communication such as manuscript in scientific journal, paper in a symposium or conference proceeding. Learning material with exposition text is a book or learning module consisted of written text that is containing the title, statement of thesis, argumentation, and rely the idea with language conjugation. It is the text that is containing content as idea or message that is intended to deliver to the reader, which has been formulated in such a way and language to bring the idea clearly to the readers (Baried \& Siti, 1985). The exposition text is a strategy to send the vision, invention and the content of explanation in the development of the new knowledge (Keraf, 2008). The tex is commonly conducted to reveal a new discovery that never been published (Marahimin, 2004). The content in exposition text is related to the process or activities procedures that can produce new scientific contribution (Yore et al., 2003). Therefore, the exposition text with a process has to be clearly written, interesting, and easy to understand. The exposition text has to be written based on the facts about the events that bring a new message to the readers. The characteristics of exposition text are containing idea and argument, objectives with scientific contribution, supported by data, the argument and discussion are based on the data analysis, and the text is provided with a conclusion (Nasucha, 2009). The structure of exposition text is consisted of introduction with thesis, content argumentation, and conclusion (Dymock, 2005). Availability of figures, diagrams, table, illustration, and schematic to support exposition text are become an additional value to the learning material.

The studies have reported that the SHS students found it to be difficult to write exposition text and to convey ideas perfectly in both oral and writing (Silaban, 2018; Tarigan, 1996). The difficulties in story telling by the students are also due to the lack of the knowledge on writing exposition text with a process (Budi, 2009). Some factors influenced difficulty to write exposition text such as disability to choose a theme, the limitation of information, feeling lazy and bored to study, and inadequate mastery of language rule (Ariningsih, 2012). The teaching method has also influenced the students' ability to write exposition text. It has been known that one way teaching method tends to make the students become inactive learner. Teaching style by explanation of the theory without bring the students into practice make the learning topic easy to forget. It has been observed in the preliminary study that first year high school students are not fully understand how to write text (Silaban, 2018). The reason for this low writing skill is probably due to the handicap faced by the teachers, such as the low students' motivation, and the lack of learning material to improve students writing skills. The purpose of the teaching programs is as a teacher learning centre. Since the teacher rely only on the textbook available in schools, therefore, the problems in the writing skills has to be improved by the development of learning material on exposition text with a process. The writing skills is needed by the students to construct text from a prepared theme. The skill to be developed is the area of cognitive, affective and psychomotor needed for students to be able to write the text in Bahasa Indonesia. The teacher helps the students to meet the competence required by national curriculum. The availability of qualified learning material can facilitate the students to improve learning activities (Mulyasa, 2007). The teacher need to design a teaching and learning material to make the learning activities become more effective and efficient, and have to be in accordance with the national curriculum. The learning material has to be designed in more attractive way to make the subject matter easier to learn and able to motivate the students to learn Bahasa Indonesia intensively and to improve students' achievement.

An effort has to be made in order to improve students' ability to write exposition text through students' involvement in the writing activities. The development of learning material on exposition text with a process is very important for Bahasa Indonesia teaching as it can be used to develop writing skills (Semingson, et al., 2015). The learning material with exposition text provides learning instruction that can help the student to construct sentences, and it became communication tool to guide the students to bring accurate information to the readers (Mantzicopoulosm \& Patrick, 2011). A good learning material can facilitate the students to become independent learners (Simatupang \& Situmorang, 2013). The learning material on exposition text contained the theory on writing skills that guide the students to proceed with it into practice to write a text in formal academic report. The study is aimed to develop a learning material on exposition text with process to be used as a learning media to improve students' competence in Bahasa Indonesia. A set of standard learning material is obtained and implemented to improve students' competence in Bahasa Indonesia. The performance of developed learning material has been analyzed to meet the requirement of competence based curriculum. The affectivity of the developed learning material to improve students' performance to write formal text was also investigated. The learning material becomes a good communication media on the teaching and learning process to bring the students to become active learners. Students' ability to write text on their own style and to express the idea in a formal text is achieved. 


\section{Research Methodology}

\subsection{Population and Sample}

The study is conducted at SMA 5 Medan, Province of North Sumatera, Indonesia, in the second semester on academic year 2017/2018. The populations are the first year SHS students majoring in science. The research was carried out with the involvement of 120 first year high school students. The samples are four classes that are purposively selected from 14 parallel classes in the school, where two classes are designed for experimental group and another two classes are treated for control group. There are about 40 students per-class but only 30 students per-class are taken for data analysis, those are the students with relatively having similar score in the pre-test. The out-layer samples, those are having high score in the pre-test, are removed from the group in the data analysis. All students are treated without discrimination during the learning activities.

\subsection{Research Procedures}

The study consisted of three main stages: (1) the development and standardization of a set of learning material on exposition text with a process that is in accordance with the national curriculum in Indonesia, (2) the preparation of research instruments of evaluation test, questionnaire, learning materials and marking criteria for students' essays, and (3) the implementation of learning material in the class, including teaching and learning activities, data collection, and data analysis. The steps are explained briefly following the procedures explained in the references (Situmorang et al., 2015).

\subsubsection{The Development of Learning Material on Exposition Text with a Process}

The development of learning material was carried out followed by preliminary studies to the availability of learning materials in the school related to the subject to be taught. The learning resources of textbooks have been analyzed for its relevancies to the students' need as required by national curriculum (Abed et al., 2015). A set of learning material was constructed by arrangging the topics suited to the national curriculum. A draft of learning material was prepared by enriching the material with contextual text examples. The learning material was then equipped with projects in relation to on exposition text with a process. The learning package was then validated by Bahasa Indonesia lecturers and teachers to evaluate the contents followed by revising it according to their comments and suggetions. Try out for small number of students has been conducted in the next stage to see the feasibility of the developed learning material to students' development (Chambliss, 2001). Finally, the learning material is then standarized for its performance based on the criteria given by Indonesian National Education Standards Board (BSNP) which focused on the content, depth, legal legibility, extension, design and language. A set of innovative learning material was then provided in printed with interesting layout.

\subsubsection{Preparation of Research Instruments}

The instruments used in this study are similar to those explained in the previous study (Situmorang et al., 2015; Sutiani et al., 2017). They are consisted sets of evaluation tests for pre-test and post-test 1, a set of standard questionnaire, a lesson material, and a form for marking criteria of submitted essays. Sets of standard evaluation tests (20 problems) are provided in multiple choice tests to be used to measure students' achievement on Bahasa Indonesia. The quality of the questions for pre-test and post-test 1 is equal and designed to cover Bahasa Indonesia subject including the writing skills on exposition text. The questionaire is used to standardize the learning material based on BSNP criteria. It consisted of the components that are used as indicators to assess the feasibility of learning material. A set of lesson plan is provided as a general guide in the teaching and learning activities for both experimental class and control class. The marking system for submitted essays is conducted by using standardized rubric for a written text on exposition text with a process. The marks are coming from three parts, the contents, the language, and the format (Pujiono, 2012). The contents are assessed from how deep the idea is been constructed in the written text format. The language is categorized into dictions; sentences; paragraphs; spellings and punctuations. The format explained the writing technique for essays; those are including font, margin, layout, presentation of figure and table, style, and coherency. The text has to be assessed in a whole message that is coming from story contents, writing organization, vocabulary, and language development (Nurgiyantoro, 2001).

\subsubsection{Teaching and Learning Activities, Data Collection, and Data Analysis}

Implementation of the developed learning material is performed to the high school students. The pre-test was carried out before teaching and learning activities to investigate the students' knowledge on exposition text with a process followed by teaching and learning activities. The teaching activity is started by giving an academic instruction to use the learning material with exposition text, followed by guiding the students on how to write an essay as arranged in the lesson plan. To the experimental class, the teaching treatment was conducted by using the developed learning material to construct the knowledge on writing texts. Similar steps are done in the control class 
by using ordinary book with supplementation of writing projects. The students are all instructed to write their essays on exposition text with a process and to be submitted a week after the subject time table. The students are motivated to use school's facilities for self-learning in addition to the developed learning material and ordinary book. There are four projects asked to be completed by the students in the study. Post-test 1 was performed to measure students' achievements on the subject being taught at the end of lesson sessions. Data analysis is conducted to measure students' achievement based on their score on evaluation test and student performance from the marking portfolio of submitted essays. Students' achievement was obtained from the student's ability to answer the questions in the evaluation test, where the students' performance on writing skills were taken from marks portfolio of submitted projects. The combination results are calculated to investigate the influence of the developed learning material to improve students' competence in Bahasa Indonesia. The decision has been made based on the measurement and hypothesis testing by using statistics at $95 \%$ confident.

Table 1. Description of learning material with exposition text on the teaching of Bahasa Indonesia

\begin{tabular}{|c|c|c|c|c|}
\hline No & Sub Subject & $\begin{array}{l}\text { Short description of contents in the } \\
\text { learning material }\end{array}$ & Aims & Integrated Project \\
\hline 1. & $\begin{array}{l}\text { Introduction to } \\
\text { exposition text }\end{array}$ & $\begin{array}{l}\text { Introduction to exposition text with a } \\
\text { process, how does it apply in writing } \\
\text { academic text, including competence } \\
\text { standars and how to use learning } \\
\text { material }\end{array}$ & $\begin{array}{l}\text { To give short explanation on exposition } \\
\text { text with a porocess that been applied in } \\
\text { academic reports }\end{array}$ & $\begin{array}{l}\text { Example of exposition } \\
\text { text with a process in in } \\
\text { academic reports }\end{array}$ \\
\hline 2. & $\begin{array}{l}\text { The structure } \\
\text { and the analysis } \\
\text { of exposition } \\
\text { text with a } \\
\text { process }\end{array}$ & $\begin{array}{l}\text { Containing the structure and contents of } \\
\text { exposition text (problem, argument, } \\
\text { knowledge, and recommendation), the } \\
\text { format of exposition text with a process } \\
\text { in writing, listening and reading. The } \\
\text { material is supported by picture, } \\
\text { illustration, academic article and their } \\
\text { explanation }\end{array}$ & $\begin{array}{l}\text { 1. To guide the students to identify the } \\
\text { structure and contents of exposition text } \\
\text { in writing, listening and reading. } \\
\text { 2. To identify the format of exposition } \\
\text { text with a process for specific topic of } \\
\text { academic reports. } \\
\text { 3. To construct the language structure of } \\
\text { exposition text with a process in the text } \\
\text { of academic reports. }\end{array}$ & $\begin{array}{l}\text { Project } 1 . \text { The students } \\
\text { are given a project to } \\
\text { identify the thesis, } \\
\text { argument, and } \\
\text { recommendation in a } \\
\text { text of academic article, } \\
\text { and ask them to justify } \\
\text { whether the text is } \\
\text { grouped into fact or a } \\
\text { fiction. }\end{array}$ \\
\hline 3. & $\begin{array}{l}\text { Development of } \\
\text { contents of } \\
\text { exposition text } \\
\text { with a process } \\
\text { in oral and } \\
\text { writing } \\
\text { (problem, } \\
\text { argument, } \\
\text { recommendatio } \\
\mathrm{n})\end{array}$ & $\begin{array}{l}\text { The development of a content is started } \\
\text { by providing an article with picture with } \\
\text { a theme "Pembangunan dan kerusakan } \\
\text { lingkungan" (The development and } \\
\text { environmental damage). The stepts to } \\
\text { find the main idea and the explanation } \\
\text { idea for in each pragraph in the text are } \\
\text { provided in a systematic structure of } \\
\text { academic article }\end{array}$ & $\begin{array}{l}\text { 1. To emphasize students ability to } \\
\text { construct exposition text with a process } \\
\text { focus on the structure, contents, } \\
\text { problems, argumentation, new } \\
\text { contribution or information (knowledge), } \\
\text { recommendation, and the language. } \\
\text { 2. To give experience to present, give } \\
\text { comments, and to revise the text contains } \\
\text { exposition text with a process in } \\
\text { academic writing report }\end{array}$ & $\begin{array}{l}\text { Project } 2 \text { To complete } \\
\text { the thesis with supported } \\
\text { argument and to relay } \\
\text { back the idea in } \\
\text { exposition text in } \\
\text { different language style }\end{array}$ \\
\hline 4. & $\begin{array}{l}\text { Analysis of the } \\
\text { structure and } \\
\text { language of } \\
\text { exposition text }\end{array}$ & $\begin{array}{l}\text { The explanation on the characteristics of } \\
\text { exposition text and typical mistakes in } \\
\text { exposition text that commonly found in } \\
\text { the texts of academic report }\end{array}$ & $\begin{array}{l}\text { To find the characteristics of exposition } \\
\text { text and to analyse the mistake of } \\
\text { exposition text in the formal text of } \\
\text { academic report }\end{array}$ & $\begin{array}{l}\text { Project } 3 \text { To reveal the } \\
\text { structure of exposition } \\
\text { text with a process and } \\
\text { to compare exposition } \\
\text { text in two academic } \\
\text { texts }\end{array}$ \\
\hline
\end{tabular}


1. To give experience to write a good and correct report text through the

To construct a text containing exposition text with a process through writing of scientific report with focus on the contents (problems, argumentation, the contribution or information of new knowledge and recommendation), the structure, and the validity. construction of exposition text with a process. The writing test is focused on the contents (problems, argumentation, the knowledge and recommendation), the structure and the language.

2. To give experience and the ability to present a good text containing exposition text with a process and to revise the text to become a formal academic report
Project 4 To determine the main idea and explanation idea in the text, and rearrange the idea into exposition text in a text of academic report.

\section{Results and Discussion}

\subsection{Description of Learning Material on Exposition Text with a Process}

A set of learning material for Bahasa Indonesia has been developed well based on standard competences required in the national curriculum 2013 (Priyatni, 2014). Short description of the learning material is presented in Table 1. There are four sub chapters in the learning material: (1) the introduction to exposition text including competence standards and how to use learning material, (2) the structure and the analysis of exposition text, (3) the development of contents of exposition text in oral and writing (problem, argument, recommendation), (4) analysis of the structure and language of exposition text, and (5) Writing texts containing exposition text with process. There are four projects are integrated in the learning material to be completed by the students.

\subsection{Validation and Standardization of Learning Material}

The developed learning material was validated to see the feasibility and adequacy of the contents of Bahasa Indenesia base on national curriculum 2013 for high school. It has been validated in three rounds with accepting suggestions, followed by revision, until it suited to the need of high school students. The first stage is to validate a draft manuscript by expert (lecturers in Department of Bahasa Indonesia, Universitas Negeri Medan) to evaluate and to assess the contents adequacy in accordance with the curriculum and students development. The second stage is presenting the revised manuscript to experience high school teachers to get their comments and suggestions on the feasibility of the material for high school students, The third stage is a tryout for small number of SHS students to assess the effectivity of the material to be used as a learning media in the teaching of Bahasa Indonesia. The complete results of the validation stages are presented in the unpublish report (Silaban, 2018). Briefly, the narative in the learning material is contextual with integration of relevant examples from daily life. The learning material is easy to understand, the contents are adequate and it is systematically provided starting from easy to a difficult texts and finally abstract passages. The illustrations in the learning material are relevant, it consisted of comprehensive questions, and the projects steps available in the learning material are able to guide the students to learn Bahasa Indonesia. The developed learning material has been standardized and the respondents results are summarized in Table 2. All respondents gave positive comments to the material components, and is categorised to be excellent learning resources $(\mathrm{M}=3.76 \pm 0.42)$. The content, extention, depth, design, and the language in a developed learning material are all met the criteria required by the BSNP. The learning material was ready to be used in the class for teaching Bahasa Indonesia. 
Table 2. Respondents opinions on the feasibility and adequacy of a developed learning material. The marks are obtained from the average responses $(M \pm S D)$ from 13 respondents of Lecturers $(\mathrm{L})$ and Teachers $(\mathrm{T})$

\begin{tabular}{|c|c|c|c|c|}
\hline \multirow{2}{*}{$\begin{array}{l}\text { Book components } \\
\text { to be assessed }\end{array}$} & \multirow{2}{*}{ The criteria in the developed learning material } & \multicolumn{3}{|c|}{ Respondents Opinions } \\
\hline & & $\mathrm{L}(n=6)$ & $\mathrm{T}(n-7)$ & Average \\
\hline \multirow{2}{*}{ Content } & - The completeness of the contents on exposition text with a process & $3.67 \pm 0.52$ & $3.57 \pm 0.53$ & $3.62 \pm 0.53$ \\
\hline & - The contents and the texts are accurate & $3.67 \pm 0.52$ & $4.00 \pm 0.00$ & $3.83 \pm 0.26$ \\
\hline \multirow[t]{2}{*}{ Extension } & $\begin{array}{l}\text { - Presented the extension of learning material on exposition text } \\
\text { with a process by integration of the text from local contents and } \\
\text { contextual application }\end{array}$ & $3.67 \pm 0.52$ & $3.57 \pm 0.53$ & $3.62 \pm 0.53$ \\
\hline & - The learning material is clearly written & $3.83 \pm 0.41$ & $4.00 \pm 0.00$ & $3.92 \pm 0.20$ \\
\hline \multirow[t]{2}{*}{ Depth } & $\begin{array}{l}\text { - The material is presented in good order: introduction, main } \\
\text { concepts, examples, illustration and problem examples }\end{array}$ & $3.83 \pm 0.41$ & $3.86 \pm 0.38$ & $3.85 \pm 0.39$ \\
\hline & - The application of exposition text with a process in real life & $3.83 \pm 0.41$ & $3.71 \pm 0.49$ & $3.77 \pm 0.45$ \\
\hline \multirow{3}{*}{ Design } & - The design layout is in good format & $3.67 \pm 0.52$ & $3.71 \pm 0.49$ & $3.69 \pm 0.50$ \\
\hline & $\begin{array}{l}\text { - Supporting material of illustration, figures, the table and images } \\
\text { are relevant }\end{array}$ & $3.67 \pm 0.52$ & $3.86 \pm 0.38$ & $3.76 \pm 0.45$ \\
\hline & - Involving learners for interactive study & $3.83 \pm 0.41$ & $3.86 \pm 0.38$ & $3.85 \pm 0.39$ \\
\hline \multirow{3}{*}{ Language } & $\begin{array}{l}\text { The language is written in accordance with the students } \\
\text { development }\end{array}$ & $3.50 \pm 0.55$ & $3.86 \pm 0.38$ & $3.68 \pm 0.46$ \\
\hline & $\begin{array}{l}\text { - The language applied in the text is easy to read, simple and } \\
\text { straighforward }\end{array}$ & $3.67 \pm 0.52$ & $3.86 \pm 0.38$ & $3.76 \pm 0.45$ \\
\hline & - The use of Bahasa Indonesia terms are accurate & $3.67 \pm 0.52$ & $3.86 \pm 0.38$ & $3.76 \pm 0.45$ \\
\hline Average & & $3.71 \pm 0.48$ & $3,81 \pm 0.36$ & $3.76 \pm 0.42$ \\
\hline
\end{tabular}

Note. $4=$ Excellent/very interesting/very easy/very clear /precise; $3=$ good/interesting/easy/clear/accurate; $2=$ $\mathrm{bad} / \mathrm{unattractive/difficult/unclear/unprecise;} \mathrm{and} 1$ = below average/poor/worst/inaccurate.

\subsection{Implementation of Learning Material in the Class}

The results from pre-test have been obtained before the teaching and learning activities with intention to measure students' knowledge on Bahasa Indonesia. The results are presented in Table 3. Most of students with having low achievement in Bahasa Indonesia and some of them are with high knowledge on Bahasa Indonesia. The outlier samples with having high score in pre-test were rejected from the groups and only relatively homogen samples are included in the data analysis. Students' achievement in experimental class $(\mathrm{M}=36.50 \pm 4.71)$ and control class $(\mathrm{M}=36.58 \pm 4.15)$ are having the same starting knowledge on Bahasa Indonesia. The samples are ready to be taught with different treatments on the teaching of Bahasa Indonesia.

Table 3. Students' achievements (pre-test and post-test 1) based on students' ability to solve multiple choice test on Bahasa Indonesia

\begin{tabular}{ccccccc}
\hline & \multicolumn{5}{c}{ Students' achievements from the average score $(M \pm S D)$} \\
\cline { 2 - 7 } Evaluation tests & \multicolumn{5}{c}{ Control Class } \\
\cline { 2 - 7 } & X IPA-1 $(n=30)$ & X IPA-3C $(n=30)$ & Average & X IPA-2 $(n=30)$ & X IPA-4 $(n=30)$ & Average \\
\hline Pre-test & $35.33 \pm 6.01$ & $37.67 \pm 3.41$ & $36.50 \pm 4.71$ & $35.33 \pm 4.14$ & $37.83 \pm 4.17$ & $36.58 \pm 4.15$ \\
Post-test 1 & $89.50 \pm 6.45$ & $89.77 \pm 4.19$ & $89.63 \pm 5.32$ & $76.17 \pm 5.33$ & $78.33 \pm 4.79$ & $77.25 \pm 5.06$ \\
\hline
\end{tabular}

The students in experimental and control class are then taught the same topics as listed in the lesson plan. In this regard, the experimental groups are given a set of developed learning material on exposition text with a process, while the control groups are provided with ordinary students' books that are available in the school. Another parameter such as the teachers, the time length, and the learning facilities are kept to be similar in both groups. At the end of the study sessions, the students are provided with post-test 1 to assessed students' knowledge on delivered topics. Students' achievement resulted from post-test 1 is summarized in Table 3. The students in experimental class $(\mathrm{M}=89.63 \pm 5.32)$ are having higher score compared to the score in control class $(\mathrm{M}=77.25 \pm 5.06)$. The results have revealed that the use of learning material influence students' knowledge on Bahasa Indonesia. In addition to the students' achievement in Bahasa Indonesia, the students' performance to write texts, that were the students projects to be completed during their learning session. The students in both groups 
submitted their essays on time. The students are able to complete the assignments with good results. The students' performance in writing texts that were obtained from mark portfolio of submitted essays are presented in Table 4 . The results showed that the average marks in experimental class $(M=86.04 \pm 6.89)$ are higher than that achieved in control class ( $\mathrm{M}=78.60 \pm 5.42)$.

Table 4. Students' performance on writing texts on Bahasa Indonesia that was obtained from portfolio of submitted essays

\begin{tabular}{ccccccc}
\hline & \multicolumn{4}{c}{ Students' mark on writing $(M \pm S D)$ from portfolio of submitted assignment } \\
\cline { 2 - 7 } Mark Portfolio of Projects & \multicolumn{3}{c}{ Experimental Class } & \multicolumn{3}{c}{ Control Class } \\
\cline { 2 - 7 } & X IPA-1 $(n=30)$ & X IPA-3 $(n=30)$ & Average & X IPA-2 $(n=30)$ & X IPA-4 $(n=30)$ & Average \\
\hline Assay 1 & $82.63 \pm 7.42$ & $86.23 \pm 4.01$ & $84.43 \pm 5.72$ & $79.10 \pm 6.18$ & $82.43 \pm 2.10$ & $79.48 \pm 4.14$ \\
Assay 2 & $85.67 \pm 7.39$ & $83.00 \pm 6.52$ & $84.33 \pm 6.95$ & $79.50 \pm 2.11$ & $77.27 \pm 6.94$ & $77.78 \pm 4.53$ \\
Assay 3 & $87.20 \pm 6.85$ & $87.33 \pm 8.67$ & $87.27 \pm 7.76$ & $80.63 \pm 5.24$ & $79.87 \pm 7.28$ & $78.95 \pm 6.26$ \\
Assay 4 & $89.03 \pm 6.99$ & $87.23 \pm 7.25$ & $88.13 \pm 7.12$ & $77.47 \pm 7.77$ & $76.07 \pm 5.72$ & $78.19 \pm 6.75$ \\
\hline Average & $86.13 \pm 7.16$ & $85.95 \pm 6.61$ & $86.04 \pm 6.89$ & $79.18 \pm 5.32$ & $78.91 \pm 5.51$ & $78.60 \pm 5.42$ \\
\hline
\end{tabular}

\subsection{Discussion}

The development of learning material on exposition text with a process has been done well to produce excellent learning resources for high school students. The learning material has been arranged in good order contained simple to complex examples of exposition text with a process that can be used to guide the students to construct their writing skills. The validation results have showed that the respondents are satisfied with the feasibility and the adequacy of the Bahasa Indonesia contents in the developed learning material. Positive comments are given to express a high quality of the material. It has been written suited to the national curriculum and suited to the students' development (Situmorang, et al., 2015). The developed learning material has been presented in various formats at different situation and conditions that can be applied in formal and informal instructions such as observation report, negotiation between both sides, statement of objection and critiques (Sinatra \& Broughton, 2011). The text in the learning material has also been made as literature genre that can explore and explain different social conditions such as factual genre and response genre. The example in the learning material has been provided as exposition text beside the descriptive response text, observed text, explanation text, short story text, and anecdotal text (Sarie, 2017). The text provided in learning material has advantage in the simplicity of the learning material as they can use it anytime and anywhere when they intend to complete their essay assignments (Martínez-Lirola \& Rubio, 2009). The example that has been integrated in the manuscript is contextual from their experience in their environments (Situmorang, 2013). The manuscript is categorized as a good resource and worth to be used as learning media in the teaching of Bahasa Indonesia. The contents of exposition text with a process integrated in the learning material are adequate to guide the students to write text.

A high quality learning material guided the students be able to solve their study problems (Tompkins et al., 2006). The students in both classes are having desire to learn Bahasa Indonesia, where both class are having high achievements in the post-test 1 and also with high performance in writing. The students are able to submit their essays on time and resulting in good marks (see results in table 3 and table 4). Most of submitted essays in both groups are written in very good format where they are consisted of the introduction, the problems and the thesis, the supported data, and conclusion (Moss, 2004). Experimental class used the developed learning material as a main resource in learning activities and in completing the projects (Sinaga \& Situmorang, 2015). The submitted essays in experimental class are all written in a good structure followed the guideline given in the learning material that results in very high marks. The learning facilities in the material are able to help students to learn Bahasa Indonesia in addition to the information given by the teachers in the class (Bernabei \& Heinemann, 2012). The illustrations and figures integrated in learning material are found to be very effective to guide the students to learn Bahasa Indonesia. The availability of contextual examples in learning materials is used as a "model" to guide the students to write their essays correctly. The students are able to write the essays from daily life experience (Mantzicopoulosm \& Patrick, 2011). It has been revealed that the learning material on exposition text used in the study is effective to improve students' achievement in Bahasa Indonesia. Improvement in the students' achievement and students' performance is due to the improvement in the students' motivation to study Bahasa Indonesia by the help of the developed learning material (Sinatra \& Broughton, 2011). With the clear information provided in the text make the students can express their idea systematically, clearly, and completely through exposition text in their submitted essays. 


\section{Conclusion}

A standard learning material of Bahasa Indonesia on exposition text with a process for senior high school students has been developed well suited to national curriculum in Indonesia. The material consisted of five sub-chapters covering the theory on exposition text, the contextual example on exposition text with process, supporting materials containing figures, tables and illustration, and guided projects to be followed to write texts in formal academic reports. The facilities available in the developed learning material were able to guide the students to study Bahasa Indonesia. A set of the developed learning material on exposition text with a process has been found to be a useful resource to help the students to write texts correctly, and be able to improve students' achievement on Bahasa Indonesia.

\section{Acknowledgements}

The author expresses many thanks to Tiur Asi Siburian lecturers in The Department of Bahasa Indonesia, Faculty of Language and Arts, Universitas Negeri Medan, and Bangkit Agustina Harianja the teachers of SMA 5 Medan Sumatera Utara for their help to do research. The help from Maya Oktora from International Office Universitas Negeri Medan for editing process is also gratefully acknowledged.

\section{References}

Abed, E. R., \& Al-Absi, M. M. (2015). Content Analysis of Jordanian Elementary Textbooks during 1970-2013 as Case Study. International Education Studies, 8(3), 159-166. https://doi.org/10.5539/ies.v8n3p159

Ariningsih, N. E. (2012). Analisis Kesalahan Berbahasa Indonesia dalam Karangan Eksposisi Siswa Sekolah Menengah Atas. BASASTRA, 1(1), 41. Retrieved from https://www.neliti.com/id/publications/55073/analisis -kesalahan-berbahasa-indonesia-dalam-karangan-eksposisi-siswa-sekolah-me

Baried, \& Siti, B. (1985). Pengantar Teori Filologi. Jakarta: Pusat Pembinaan dan Pengembangan Bahasa Departemen Pendidikan dan Kebudayaan.

Bernabei, G., \& Heinemann, D. H. (2012). The story of my thinking: expository writing activities for 13 teaching situations. Heinemann Educational Books.

Budi, E. N. (2009). Hubungan Antara Kecerdasan Emosional dan Penguasaan Struktur Kalimat dengan Kemampuan Menulis Eksposisi (Survei di SMP Negeri Kecamatan Jekulo Kabupaten Kudus 2008/2009). Tesis, Program Pascasarjana Universitas Sebelas Maret Surakarta.

Chambliss, M. J. (2001). Analyzing science textbook materials to determine how "persuasive" they are. Theory into Practice, 40(4), 255-264. https://doi.org/10.1207/s15430421tip4004_7

Dymock, S. (2005). Teaching expository text structure awareness. The Reading Teacher, 59(2), 177-182. https://doi.org/10.1598/RT.59.2.7

Holliday, W. G. (2002). Selecting a science textbook. Science Scope, 25(4), 16-20.

Keraf, G. (2008). Eksposisi dan Narasi. Nusa Indah, Ende-Flores.

Kirsch, I. S., \& Mosenthal, P. B. (1992). Learning from exposition: Understanding process knowledge models. Journal of Reading, 35(6), 490-497.

Kosasih, E. (2014). Jenis-jenis Teks: Analisis Fungsi, Struktur, dan Kaidah serta Langkah-langkah Penulisannya. Bandung: Yrama Widia.

Mantzicopoulosm, P., \& Patrick, H., (2011). Reading picture books and learning science: engaging young children with informational text. Theory into Practice, 50, 269-276. https://doi.org/10.1080/00405841.2011.607372

Marahimin, I. (2004). Menulis Secara Populer. Dunia Pustaka. Jakarta.

Martínez-Lirola, M., \& Rubio, F. (2009). Students' beliefs about portfolio evaluation and its influence on their learning outcomes to develop EFL in a Spanish context. IJES, 9(1), 91-111.

Moss, B. (2004). Teaching expository text structures through information trade book retellings. The Reading Teacher, 57(8), 710-718. Retrieved from https://www.jstor.org/stable/20205422?seq=1\#page_scan_tab_ contents

Mulyasa, E. (2010). Kurikulum Tingkat Satuan Pendidikan. PT Remaja Rosdakarya Offset: Bandung

Nasucha, Y. (2009). Bahasa Indonesia untuk Penulisan Karya Tulis Ilmiah. Media Perkasa, Yogyakarta.

Nurgiyantoro, B. (2001). Penilaian dalam Pengajaran Bahasa dan sastra Indonesia. BPRE-Yogyakarta, 
Yogyakarta.

Priyatni, E. T. (2014). Desain Pembelajaran Bahasa Indonesia dalam Kurikulum 2013. Bumi Aksara, Jakarta.

Pujiono, S. (2012). Terampil Menulis Cara Mudah dan Praktis dalam Menulis. Graha Media, Yogyakarta.

Sarie, R. F. (2017). Exploring the possibility of using both direct and indirect corrective feedback as strategy to improve students' writing skill in indonesian secondary school. International Journal of Arts \& Sciences, 9(4), 597-604. Retrieved from https://search.proquest.com/openview/7e25f26ddb3311b766bac971f620737b $/ 1$ ? pq-origsite $=$ gscholar $\& \mathrm{cbl}=626342$

Semingson, P., Pole, K., \& Tommerdahl, J. (2015). Using Bilingual Books to Enhance Literacy Around the World. European Scientific Journal, 3, 1857-7881.

Silaban, W. (2018). Pengembangan Bahan Ajar Teks Ekposisi Berbasis Proses Untuk Siswa Kelas X SMA. Tesis, Program Pascasarjana, Universitas Negeri Medan.

Simatupang, N. I., \& Situmorang, M. (2013). Innovation Of Senior High School Chemistry Textbook To Improve Students Achievement In Chemistry. Proceeding of The $2^{\text {nd }}$ International Conference of the Indonesian Chemical Society 2013 at UII Yogyakarta, Indonesia, October, 22-23 2013 (pp. 44-52).

Sinaga, M., \& Situmorang, M. (2015). Pengembangan bahan ajar berbasis kontekstual untuk meningkatkan hasil belajar mahasiswa pada pengajaran reaksi redoks (The development of contextual learning material to improve students achievement on the teaching of redox reaction). Prosiding Seminar Nasional dan Rapat Tahunan BKS PTN-B bidang MIPA di Universitas Tanjungpura Pontianak 2015 (pp. 549-558). Retrieved from http://jurnal.untan.ac.id/index.php/semirata2015/issue/view/455/showToc

Sinatra, G. M., \& Broughton, S. H. (2011). Bridging reading comprehension and conceptual change in science education: The promise of refutation text. Reading Research Quarterly, 46(4), 374-393. https://doi.org/10.1002/RRQ.005

Situmorang, M. (2013). Pengembangan buku ajar kimia sma melalui inovasi pembelajaran dan integrasi pendidikan karakter untuk meningkatkan hasil belajar siswa [The development of high school chemistry textbook through learning innovation and integration of character education to improve students achievement]. Prosiding Seminar dan Rapat Tahunan BKS PTN-B Bidang MIPA di Bandar Lampung 10-12 Mei 2013 (pp. 237-246). Retrieved from http://jurnal.fmipa.unila.ac.id/index.php/semirata/article/view/817

Situmorang, M., Sitorus, M., Hutabarat, W., \& Situmorang, Z. (2015). The Development of innovative chemistry learning material for bilingual senior high school students in Indonesia, International Educational Studies, 8(10), 72-85. https://doi.org/10.5539/ies.v8n10p72

Sutiani, A., Silalahi, A., \& Situmorang, M. (2017). The development of innovative learning material with problem based approach to improve students competence in the teaching of Physical chemistry. Proceeding of $2^{\text {nd }}$ Annual International Seminar on Transformative Education and Educational Leadership (AISTEEL 2017). https://doi.org/10.2991/aisteel-17.2017.81

Tompkins, C. J., Rosen, A. L., \& Larkin, H. (2006). Guest editorial: an analysis of social work textbooks for aging content: How well do social work foundation texts prepare students for our aging society? Journal of Social Work Education, 42(1), 3-24. https://doi.org/10.5175/JSWE.2006.042110001

Yeti, B. (2011). Minat Belajar Siswa Terhadap Mata Pelajaran Bahasa Indonesia (studi kasus di SMA PGRI 56 Ciputat). Skripsi, UIN Syarif Hidayatullah Jakarta.

Yore, L. D., Bisanz, G. L., \& Hand, B. M. (2003). Examining the literacy component of science literacy: 25 years of language and science research. International Journal of Science Education, 25(6), 689-725. https://doi.org/10.1080/09500690305018

\section{Copyrights}

Copyright for this article is retained by the author(s), with first publication rights granted to the journal.

This is an open-access article distributed under the terms and conditions of the Creative Commons Attribution license (http://creativecommons.org/licenses/by/4.0/). 